\title{
Effects of storage duration on haematological parameters of the red eared slider -
} Trachemys Scripta Elegans

Nejra Hadžimusič ${ }^{*}$ Dunja Rukavina, Vedad Škapur and Lejla Velić

\begin{abstract}
Reptiles, especially turtles, are becoming increasingly popular as pets. The haematological evaluation of turtles is an irreplaceable diagnostic tool in veterinary practice. However, the morphologic distinctiveness of turtle blood limits the use of electronic cell-counting devices, making time-consuming, manual counting techniques and evaluation of blood smears necessary. Many samples are dispatched to a laboratory over long distances, where a delay of $24 \mathrm{~h}$ or more may occur. At weekends, this interval may exceed $48 \mathrm{~h}$. The objective of the present study was to determine the effect of storage duration at refrigerator temperature $\left(4^{\circ} \mathrm{C}\right)$ on the counts of red blood cells (RBC) and white blood cells (WBC), and on the mean corpuscular volume (MCV) and packed cell volume (PCV) in blood samples from healthy adult red-eared sliders. Blood samples were collected by venipuncture from the occipital venous sinus from six apparently healthy
\end{abstract}

adult red-eared sliders, aged 2 to 4 years. Blood samples were analysed immediately after sampling to obtain the baseline value (BV) of the red blood cell count, white blood cell count and packed cell volume percentage. Blood was stored at $4{ }^{\circ} \mathrm{C}$ and the haematological analyses were performed after $24 \mathrm{~h}, 48 \mathrm{~h}$ and $72 \mathrm{~h}$. The results showed the same level of stability for RBC and WBC count, and MCV values during 72 hours of storage at $4{ }^{\circ} \mathrm{C}$ and for PCV during 48 hours. Handling of blood samples, and duration of storage of the blood samples can significantly influence the results/values of haematological tests. Consequently, the obtained values of the determined haematological parameters of improperly stored or handled blood samples can give a misleading interpretation of the results on the animal's health status.

Key words: Erythrocytes count; haematocrit value; leukocyte count; storage duration; turtles

Nejra HADŽIMUSIĆ*, DVM, PhD, Assistant Professor, (Corresponding author, e-mail: nejra.hadzimusic@ vfs.unsa.ba), Dunja RUKAVINA, biologist, PhD, Associate Professor, Veterinary Faculty, University of Sarajevo, Sarajevo, Bosnia and Herzegovina; Vedad ŠKAPUR, DVM, PhD, Assistant Professor, Faculty of Agriculture and Food Sciences, University of Sarajevo, Sarajevo, Bosnia and Herzegovina; Lejla VELIĆ, DVM, PhD, Assistant Professor, Veterinary Faculty University of Sarajevo, Sarajevo, Bosnia and Herzegovina 


\section{Introduction}

Due to the rising popularity of the redeared slider as a pet, turtles are becoming routine patients in veterinary practices. Haematological analysis is normally used to evaluate animal health. Combining the clinical presentation with haematologic results gives valuable information for the diagnosis and monitoring of disease in reptiles, and helps guide the clinician toward therapy and further diagnostic testing (Stacey et al., 2011). However, the clinician can experience certain limitations, such as difficulties in collecting blood samples due to the turtle's ability to retract the body into the protective shell, and due to the small amount of blood that can be sampled, since the blood volume of reptiles is thought to be between $5-8 \%$ of the total body weight. Several studies have described characteristics of the reptilian blood profile (Stacy et al., 2011; Nardini et al., 2013; Sykes and Klaphake, 2015; Hernandez et al., 2017). It is well known that reptilian haematology parameters may be influenced by many factors, such as age, sex, seasonality, and reproduction (Hidalgo-Vila et al., 2007), though venipuncture site, hibernation status, captivity status, and environmental factors can also affect values, making the interpretation of haematology results challenging (Hadžimusić et al., 2010; Nardini et al., 2013; Sykes and Klaphake, 2015).

One of the most challenging aspects in the diagnostic haematology of reptiles is the accuracy of cell counts. It is very important to use the proper anticoagulant. The most commonly used anticoagulant for reptiles is heparin, since EDTA causes haemolysis. In addition, the presence of nucleated red blood cells and thrombocytes in reptile blood limits the use of automatic cell-counting devices, making manual counting techniques and evaluation of blood smears essential in health assessment. Despite multiple sources of error (inadequate mixing or dilution of blood and stains, incorrect charging of the haemacytometer chamber, and errors in differentiating leukocytes from thrombocytes), the NattHerrick method for obtaining blood cell counts remains the most used method. However, this method requires a welltrained and experienced professional, and is also very time-consuming.

The results of the haematology tests are often influenced by the time between blood sampling and measurement, and storage conditions (e.g., time) during sample delivery between laboratories may further affect the data (Hadžimusić et al., 2010). Since the manual procedure (instead of automated haematology analysers) is used most often, reptilian blood samples might not be analysed immediately upon receipt at the laboratory, but are instead kept in the refrigerator.

Research conducted on different animal species has shown significant differences in the stability of the values of various haematological tests of blood samples stored for longer periods at refrigerator temperature (Ihedioha and Onwubuche, 2007; Fazio et al., 2016). A study conducted on bovine blood showed that refrigeration had a stabilizing effect on the red blood cell count, but led to a decrease in the white blood cell count after 24 hours of storage (Okorie-Kanu and Solomon, 2015).

The purpose of this study was to detect changes in the haematological test parameters: red blood cell count (RBC), white blood cell count (WBC), packed cell volume (PCV) and mean corpuscular volume (MCV) of red-eared slider blood samples, stored for up to 72 hours in the refrigerator $\left(4^{\circ} \mathrm{C}\right)$.

\section{Materials and methods}

Turtles were kept in captivity at the Sarajevo Zoo. Animals were handled 
according to the usual management in their habitat (Sarajevo Zoo - Pionirska dolina, Sarajevo, Bosnia and Herzegovina; $43^{\circ} 52^{\prime} 41.8^{\prime \prime} \mathrm{N} 18^{\circ} 24^{\prime} 44.1^{\prime \prime} \mathrm{E}$; elevation 518 $\mathrm{m})$. Water temperature was kept between $24{ }^{\circ} \mathrm{C}$ and $28^{\circ} \mathrm{C}$, and the basking area temperature was about $29{ }^{\circ} \mathrm{C}$ to $33{ }^{\circ} \mathrm{C}$. All temperatures were monitored with the use of thermometers. To maintain a healthy circadian rhythm, the lights in the slider habitat were on for 10-12 hours a day, ensuring adequately long nights. All animals were older than 1 year of age, ranging from 2 to 4 years. Average weight was $0.966 \mathrm{~kg}$ (Min/Max: 0.8 - $1.1 \mathrm{~kg}$ ). Each turtle was weighed with a precision of $\pm 0.1 \mathrm{~kg}$.

Blood samples were collected from six apparently healthy adult red-eared sliders during the summer season. Only turtles that were active, eating well, and not on any major treatments were included. Blood samples $(0.5-0.7 \mathrm{~mL})$ were taken during morning hours from the occipital venous sinus (Hidalgo-Vila et al., 2007) using a disposable sterile syringe with a 0.6-gauge (23G) needle into vacutainer á $4 \mathrm{~mL}$ with lithium heparin. The occipital sinus is located caudal to the skull. The neck had to be flexed and the needle was inserted caudal and ventral to the tip of the occipital process, and directed towards the tip of the nose.

Blood samples were analysed by the Natt Herrick method immediately after sampling to obtain the baseline value (BV) of the red blood cell count, white blood cell count and packed cell volume. The Natt-Herrick method is a direct counting method that can be used to obtain RBC and WBC counts. One disadvantage of this method is that blood cells tend to aggregate in the haemacytometer chamber. This can be avoided by charging the haemacytometer immediately after mixing the blood and stain.

A 1:200 dilution was made with a standard red blood cell-diluting pipette.
The haemacytometer was charged and counted and the cell count was calculated taking the number of squares counted and the dilution into account.

PCV was measured after centrifuging the blood sample in a haematocrit tube at $3500 \times \mathrm{g}$ for $5 \mathrm{~min}$ (Tehtnica, Železnik, Slovenia), while the mean corpuscular volume (MCV) was calculated.

After the baseline values were obtained, the blood was stored at $4{ }^{\circ} \mathrm{C}$ and the actual haematological analyses were performed after $24 \mathrm{~h}, 48 \mathrm{~h}$ and $72 \mathrm{~h}$, respectively. Due to volume deficiency of blood samples, only five samples were analysed after 72 hours of storage.

The study results were presented as mean values with standard errors of the mean (SEM) of each parameter determined at specific time intervals starting from the BV. Data was analysed for statistical differences using ANOVA and the result of each determination was compared with the BV. The difference between observations was considered significant at $P<0.05$.

\section{Results}

The highest RBC count was determined after 72 hours of storage $\left(0.34 \pm 0.2 \times 10^{6} / \mu \mathrm{L}\right)$ (Fig. 1). However, there were no statistically significant differences for RBC count between BV $\left(0.24 \pm 0.03 \times 10^{6} / \mu \mathrm{L}\right)$ and values obtained in blood samples stored at $4{ }^{\circ} \mathrm{C}$ for 72 hours $(P>0.05)$. RBC count remained unchanged at $4^{\circ} \mathrm{C}$ at both $24 \mathrm{~h}(0.27 \pm 0.04$ $\left.\times 10^{6} / \mu \mathrm{L}\right)$ and 48 hours $\left(0.24 \pm 0.05 \times 10^{6} /\right.$ $\mu L)$.

Although the highest WBC count was determined immediately upon collection (BV) $\left(31.8 \pm 11.77 \times 10^{3} / \mu \mathrm{L}\right)$, and the lowest WBC count was determined after 48 hours of storage $\left(18.11 \pm 5.29 \times 10^{3} /\right.$ $\mu \mathrm{L}$ ) (Fig. 2), the difference between these values was not statistically significant. Samples for WBC count showed no difference after 24 hours (20.02 $\pm 2.79 \times$ 


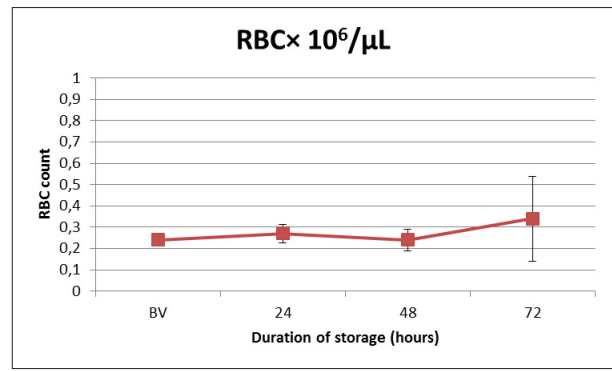

Figure 1. Changes in the RBC count (mean \pm standard error of the mean) of red eared-slider blood samples at $4^{\circ} \mathrm{C}$ over 72 hours.

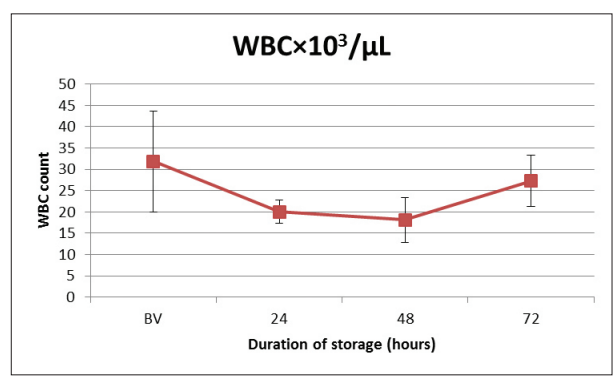

Figure 2. Changes in the WBC count (mean \pm standard error of the mean) of red eared-slider blood samples at $4^{\circ} \mathrm{C}$ during 72 hours.

$\left.10^{3} / \mu \mathrm{L}\right)$, or 72 hours of storage $(27.28$ $\left.\pm 5.94 \times 10^{3} / \mu \mathrm{L}\right)$, indicating that the duration of storage at $4{ }^{\circ} \mathrm{C}$ up to $72 \mathrm{~h}$ does not influence the WBC count.

PCV values (in \%) were $21 \pm 1.7$ for the BV; $23 \pm 2.4$ after 24 hours; $23 \pm$ 2.2 after 48 hours and $28 \pm 2.3$ after 72 hours, respectively. Therefore, PCV was higher than the base value already after 24 hours, though the increase was only statistically significant after 72 hours of storage (Fig. 3).

MCV values were $887.65 \pm 110.77$ $\mathrm{fL}$ for the $\mathrm{BV} ; 920.55 \pm 30.79 \mathrm{fL}$ after 24 hours; $1076.77 \pm 50.29 \mathrm{fL}$ after 48 hours, and $1264.15 \pm 50.94 \mathrm{fL}$ after 72 hours of storage (Fig. 4). MCV levels appear to increase over time during storage; however, the difference was not statistically significant.

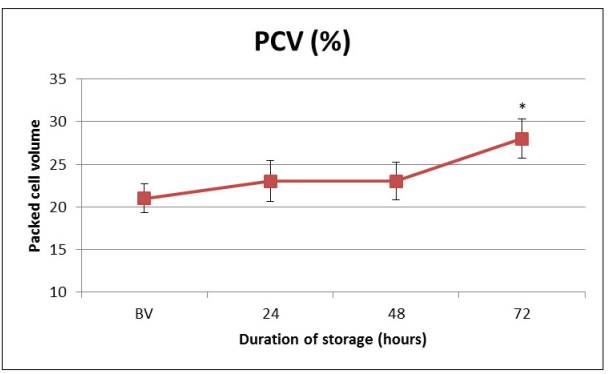

Figure 3. Changes in the PCV (mean \pm standard error of the meanl of red eared-slider blood samples at $4{ }^{\circ} \mathrm{C}$ during 72 hours. * indicates a significantly higher value $(P<0.05)$.

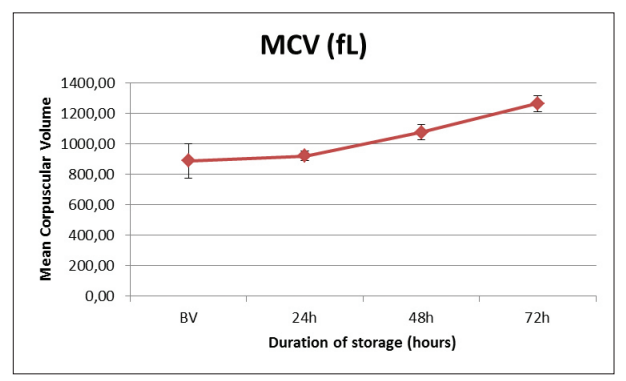

Figure 4. Changes in the MCV (mean \pm standard error of the meanl of red eared-slider blood samples at $4^{\circ} \mathrm{C}$ during 72 hours.

\section{Discussion}

For many reptile species, there are no published reference ranges for complete blood counts. To date, there are no published haematological studies on redeared slider blood parameters used in this study (Hernandez et al., 2007). Clinicians must rely on general trends and obvious changes in the haematological picture of the reptile patient (Redrobe and MacDonald, 1999).

This study showed that the RBC and WBC counts did not differ significantly after 72 hours of storage at $4{ }^{\circ} \mathrm{C}$. The PCV value determined immediately after collection (BV) showed lower values than in other small animals (20$22 \%$ ), which was also described by Mitchell (2001). PCV is used to evaluate 
the general health and hydration of the reptile patient. The lower PCV of most clinically healthy reptiles indicates a lower oxygen-carrying capacity (Stacy et al., 2011). A significantly lower PCV may occur due to lymph contamination in blood samples collected from the dorsal coccygeal vein, subcarapacial venipuncture site, or postoccipital venous plexus of chelonian species. In this study, a significant increase of PCV occurred during the storage period. The increase of PCV follows the increase of the RBC count, which had a peak after 72 hours, but without statistical significance. The increase in PCV can be attributed to the fact that the PCV is a combined measure of RBC number and sizes; though the number of RBCs does not increase, the size of cells does due to degenerative swelling (Antwi-Baffour et al., 2013). RBCs swell and increase in size/volume in blood samples kept for long because of the storage-related degenerative changes that occur in the RBCs, leading to a widening of the "pores" on the surface of the RBCs, which permit an ingress of water into the cells (Hadžimusić et al., 2010). Similar increases in PCV have also been reported in horses, cattle, pigs, goats, rats, chicken and turkeys (Hadžimusić et al., 2010). Our results show an increase of MCV values, though not statistically significant, and the MCV values were within the range reported by Diethelm and Stein (2006).

This study showed the same level of stability for RBC and WBC counts, and for $M C V$ values during 72 hours of storage at $4{ }^{\circ} \mathrm{C}$, and for PCV values during 48 hours.

Haematological parameters are valuable in monitoring animal health; however, environmental and procedural factors can affect the reported values. Based on the results, we concluded that the blood samples obtained from the red-eared slider stored up to 72 hours at $4{ }^{\circ} \mathrm{C}$ provide reliable results for $\mathrm{RBC}$ and WBC counts, and MCV values. The PCV value is reliable if the blood sample is stored up to 48 hours. The results of this study can be used as a guide to determine the appropriate storage and handling of turtle blood samples. We also recommend further research based on a larger sample size, and further general discussion of sample collection and handling.

\section{References}

1. ANTWI-BAFFOUR, S., E. QUAO, R. KYEREMEH and S. MAHMOOD (2013): Prolong Storage of Blood in EDTA Has an Effect on the Morphology and Osmotic Fragility of Erythrocytes. Int. J. Biomed. Sci. Eng. 1, 20-23.

2. DIETHELM, G. and G. STEIN (2006): Hematologic and blood chemistry values in reptiles. In: Mader, D: Reptile Medicine and Surgery. Saunders, Florida (1103-1118).

3. FAZIO, F., G. GIANGROSSO, S., MARAFIOTI, E. ZANGHI, F. ARFUSO and G. PICCIONE (2016): Blood haemogram in Ovis aries and Capra hyrcus: effect of storage time. Can. J. Anim. Sci. 96, 32-36.

4. HADŽIMUSIĆ, N., M. KATICA, Z. MUHAREMOVIĆ and J. MUŠANOVIĆ (2010): Effect of Temperature Storage on Hematological Parameters of Avian Turkey Blood. Int. J. Collab. Res. Intern. Med. Public Health. 5, 158-166.

5. HERNANDEZ, J. D., P. CASTRO, P. SAAVEDRA, P. RAMIREZ and J. OROS (2017): Seasonal variations in haematological parameters in yellowbellied slider turtles (Trachemys scripta scripta). Vet. Med. 62, 394-400.

6. HIDALGO-VILA, J., C. DÍAZ-PANIAGUA, N. PÉREZ-SANTIGOSA, A. LAZA, I. CAMACHO and F. RECIO (2007): Hematologic and Biochemical Reference Intervals of Free-Living Mediterranean Pond Turtles (Mauremys leprosa). J. Wildl. Dis. 43, 798-801.

7. IHEDIOHA, J. I. and R. C. ONWUBUCHE (2007): Artifactual changes in PCV, hemoglobin concentration and cell counts of bovine, caprine and porcine blood stored at room and refrigerator temperatures. Vet. Clin. Pathol. 36, 60-63.

8. MITCHEL, M. A. (2001): Reptile Clinical Pathology. Proceedings of the North American Veterinary Conference. Orlando, Florida.

9. NARDINI, G., S. LEOPARDI and M. BIELLI (2013): Clinical hematology in reptilian species. Vet. Clin. North. Am. Exot. Anim. Pract. 16, 1-30.

10. OKORIE-KANU, C. O. and A. U. SOLOMON (2015): Artifactual changes in the haematological values of cultured Hetroclarias hybrid blood stored 
at room and refrigerator temperatures. Comp. Clin. Pathol. 24, 1451.

11. REDROBE, S. and J. MACDONALD (1999): Sample collection and clinical pathology of reptiles. Vet. Clin. North Am. Exotic Anim. Pract. 2, 709-730.
12. STACY, N. I., A. R. ALLEMAN and K. A. SAYLER (2011): Diagnostic hematology of reptiles. Clin. Lab. Med. 31, 87-108.

13. SYKES, J. M. and E. KLAPHAKE (2015): Reptile Hematology. Clin. Lab. Med. 35, 661-680.

\section{Utjecaj vremena skladištenja na hematološke pokazatelje crvenouhe kornjače - Trachemys Scripta Elegans}

Dr. sc. Nejra HADŽIMUSIĆ, dr. med. vet, docentica, dr. sc. Dunja RUKAVINA, dipl. biolog, izvanredna profesorica, Veterinarski fakultet Univerziteta u Sarajevu, Sarajevo, Bosna i Hercegovina; dr. sc. Vedad ŠKAPUR, dr. med. vet, docent, Poljoprivredno-prehrambeni fakultet Univerziteta u Sarajevu, Sarajevo, Bosna i Hercegovina; dr. sc. Lejla VELIĆ, dr. med. vet., docentica, Veterinarski fakultet Univerziteta u Sarajevu, Sarajevo, Bosna i Hercegovina

Reptili su, posebno kornjače sve popularniji kao kućni ljubimci. Hematološka procjena kornjača je nezaobilazna dijagnostička metoda u rutinskoj veterinarskoj praksi. Ipak, neke morfološke osobitosti krvi kornjača ograničavaju mogućnost uporabe automatiziranih brojača krvnih stanica te je neophodno koristiti manualne tehnike brojenja i/ili procjenu krvnog razmaza, što zahtijeva znatno više vremena za određivanje hematoloških pokazatelja. Znatan broj uzoraka do laboratorija za obradu stižu s velikih udaljenosti te vrijeme pohrane uzorka prije same obrade može biti i dulje od 24 sata. U dane vikenda, vrijeme do obrade uzorka može biti i dulje od 48 sati. Cilj je našeg istraživanja bio ustanoviti utjecaj vremena skladištenja uzorka krvi crvenouhe kornjače čuvanih na temperaturi u hladnjaku od $4{ }^{\circ} \mathrm{C}$ na neke hematološke pokazatelje (eritrocite, leukocite, prosječna zapremina eritrocita, hematokritsku vrijednost). Krv je uzorkovana od šest odraslih, klinički zdravih crvenouhih kornjača venepunkcijom okcipitalnog venskog sinusa. Životinje su bile starosti 2 do 6 godina. Neposredno nakon uzorkovanja, krv je analizirana u cilju dobivanja baznih vrijednosti (BV) ispitivanih pokazatelja. Krv je potom skladištena na temperaturi od $4{ }^{\circ} \mathrm{C}$ i isti hematološki pokazatelji su ponovno određivani nakon 24h, 48h i 72h. Rezultati istraživanja pokazuju jednaku razinu stabilnosti za vrijednost broja eritrocita i leukocita te vrijednost prosječne zapremine eritrocita tijekom $72 \mathrm{~h}$ skladištenja na temperaturi $\mathrm{u}$ hladnjaku od $4{ }^{\circ} \mathrm{C}$ dok je hematokritska vrijednost pri navedenoj temperaturi stabilna do $48 \mathrm{~h}$. Iz navedenog smo zaključili da na rezultate hematoloških istraživanja utječe način manipulacije uzorkom, odnosno vrijeme skladištenja krvi. Stoga, vrijednosti hematoloških pokazatelja neprikladno skladištenih uzoraka krvi mogu dovesti do netočnih rezultata istraživanja i njihove krive interpretacije ili nepravilne procjene zdravstvenog statusa životinje.

Ključne riječi: broj eritrocita, hematokritska vrijednost, prosječna zapremina eritrocita, broj leukocita, kornjače 